Tér és Társadalom 23. évf. 2009/4. 173-187. p.

Tér és Társadalom

XXIII. évf. 2009 4: 173-224

\title{
KITEKINTŐ
}

\section{AZ OROSZ IPAR TÖRTÉNETI FEJLŐDÉSÉNEK POLITIKAI, ÁGAZATI ÉS TÉRBELI VONATKOZÁSAI}

\author{
(The Political, Structural and Spatial Aspects of the Historical \\ Development of the Russian Industry)
}

\section{GYURIS FERENC}

Kulcsszavak:

Oroszország indusztrializáció gazdaságpolitika ágazatiszerkezet ipari térszerkezet

Oroszország ipara érdekes lenyomatát adja az ország fordulatokban gazdag történelmének. A cári idöszak, az - iparfejlesztési szempontból sem egységes - szovjet éra, valamint a rendszerváltozás óta eltelt szük két évtized indusztrializációs folyamatai gyökeresen eltérö gazdasági feltételrendszer mellett, markánsan különbözó politikai mot́tumok mentén játszódtak le. A tanulmány e három korszak iparosodásiliparositási tendenciáit tekinti át összehasonlitó szempontból, különös tekintettel a politikai motívumokra, valamint az ipari szektor ágazati és területi szerkezetének változásaira.

\section{Bevezetés}

A bő hét évtizedes, kudarcot vallott „szocialista kísérlet” után a piacgazdasági fejlődés útjára lépő Oroszország 2008-as adatok szerint a bruttó hazai termék tekintetében a 14., míg ipari termelési érték tekintetében a 12. helyet foglalja el a világ országainak rangsorában (CIA World Factbook 2008). Bár Földủnk legnagyobb területú állama ezek alapján jócskán elmarad a gazdasági termelés nemzetközileg meghatározó szereplőitől, gazdaság- és ipartörténeti szempontból különös figyelmet érdemel, több okból:

- Oroszország ,jogelődje”, a Szovjetunió történelme során rendkívül dinamikus ipari növekedést mutatott föl: részesedése a világ ipari termeléséből a kezdeti 3\%-ról 1980-ra 20\%-ra emelkedett, ezzel agrárországból a Föld második ipari hatalmává lépett elö (Krajkó 1987, 36-38). Bizonyos, elsősorban katonai vonatkozású ágazatokban mennyiségi és minőségi tekintetben is a nemzetközi élmezönybe került.

- A Szovjetunió a szocialista világ vezető hatalmaként sajátos, a kapitalista „első” és a fejlődő „harmadik” világétól egyaránt eltérő gazdaságpolitikát folytatott, ami az ipar ágazati és területi szerkezetére, ennek társadalmi vonatkozásaira markánsan rányomta a bélyegét. 
Gyuris Ferenc : Az orosz ipar történeti fejlödésének politikai, ágazati és térbeli vonatkozásai.

Tér és Társadalom 23. évf. 2009/4. 173-187. p.

- Oroszország az egyetlen nagyhatalom, amely gazdasági és politikai tekintetben is keresztülment a szocializmusból kivezetô rendszerváltáson, méghozzá viszonylag rövid idő leforgása alatt.

A tanulmányban - a fentiek figyelembevételével - áttekintjük, miből fakadt Oroszország ipari fejlődésének jelentős megkésettsége; milyen tényezők húzódtak a szovjet korszak dinamikus iparosítási törekvéseinek hátterében; mik voltak az erőltetett indusztrializáció eredményei és sokáig rejtve maradó, de rendkívül súlyos hátulütői; és hogy milyen tendenciák érvényesülnek a szovjet örökséggel mindmáig küszködő államóriás ipari folyamataiban.

\section{Elözmények és a szovjet iparfejlesztés fö csapásirányai}

A cári Oroszország területéhez, lélekszámához mérten még a 20. század elején is szerény ipari potenciállal rendelkezett. Igaz, az 1861-es jobbágyfelszabadítás, valamint az ezt követö reformok megnyitották az utat a tőkés ipar kiépülése elött, ám ez a folyamat rendkívül lassan, térben erösen koncentráltan haladt. A foglalkoztatottak kevesebb mint tizede dolgozott az iparban (1. ábra), amely döntően (mintegy kétharmad részben) könnyűipari tevékenységeket ölelt föl. Az akkortájt legkorszerủbbnek számító (föként gép- és vegyipari) ágazatok gyakorlatilag egyáltalán nem képviseltették magukat. A gyáripari termelés zöme a nyersanyag-lelöhelyek, részint a fogyasztópiac közelében összpontosult: a kohászat 70\%-a a Donyecmedencében (melyen Oroszország ma Ukrajnával osztozik), a pamutipar 80\%-a pedig Moszkva környékén (Krajkó 1987, 36-37) - mindenekelőtt az „orosz Manchesternek" nevezett Ivanovóban (Trejvis 2008, 189-191).

Mindez szorosan összefüggött az orosz állam társadalmi berendezkedésével, politikai viszonyaival. A nyugat-európai példákhoz képest eröteljes despotikus vonásokat mutató, rendkívül nagy társadalmi különbségeket generáló és fenntartó, konzervatív orosz feudális rend akadályozta azoknak a termelési formáknak a kialakulását, amelyek hosszabb távon a mezőgazdaság termelékenységének növeléséhez, az iparfejlesztés elengedhetetlen feltételét képező tőkefelhalmozáshoz vezethettek volna. Megkésett fejlődéséből fakadóan Oroszország az Európán kívüli világrészek gyarmatosításából, az ehhez kapcsolódó „,eredeti tőkefelhalmozásból” is kimaradt; eröteljes területi terjeszkedésre ugyan sor került Szibéria és a Tengermellék bekebelezése révén, a hatalmas távolságok és a zord éghajlati adottságok azonban e térség erőforrásainak kiaknázását - ekkoriban - jórészt ellehetetlenítették. 
Gyuris Ferenc : Az orosz ipar történeti fejlödésének politikai, ágazati és térbeli vonatkozásai. Tér és Társadalom 23. évf. 2009/4. 173-187. p.

TÉT XXIII. évf. 2009 — 4

Kitekintö 175

\section{1. ÁBRA}

A foglalkoztatottak megoszlása a három gazdasági szektor között Oroszországban a mai országterületre vetítve

(The Structure of the Labour Force According to the Three Economic Sectors within the Recent Borders of the Russian Federation)

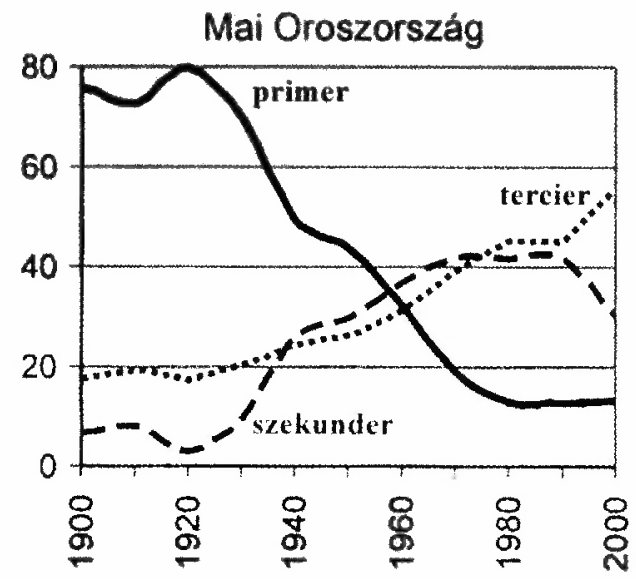

Forrás: Saját szerkesztés Trejvis (2008, 1. ábra) nyomán.

A fentiek eredményeként az orosz ipar fejlődése sokáig a szerény mértékủ külföldi tỏkeberuházásoktól függött, ezek pedig döntően olyan ágazatokba érkeztek, melyek termékeire az alacsony vásárlóerővel jellemezhetó orosz piacon is komoly kereslet ígérkezett. Így a nehézipar fejlődésének feltételei meglehetősen korlátozottak voltak, egyetlen érdemi kivétellel. Oroszország vezetői immár évszázadok óta kiemelt céljuknak tekintették az államterülethez tartozó, roppant kiterjedésủ ázsiai országrész megszervezését, ellenőrizhetővé tételét. A markáns (geo)politikai törekvés megvalósítására a 19. században érdemi lehetôség nyílt a vasút megjelenése révén. A hálózat jelentős állami forrásokból történő kiépítése viszont lehetôvé, egyben szükségessé tette a szénbányászat, kohászat és vasúti jármủgyártás felfutását. Ez a tendencia az ipar bizonyos fokú térbeli dekoncentrációját is elősegítette, mivel az új bányászati, kohászati központok zöme a transzszibériai vasút ázsiai szakasza mentén létesült (többek között a később Szibéria fő ipari körzetévé előlépő Kuznyeckimedence fejlödése is ekkor vette kezdetét) (Klüter 1997, 725).

Az orosz ipar egyébként is lassú kibontakozását az I. világháború, az ehhez kapcsolódó gazdasági összeomlás, illetve a társadalmi feszültségek nyomán kibontakozó polgárháború megtörte: az ország ipari kibocsátása 1920-ra az 1913-as szint hetedére zuhant, a textil-és acélipar visszaesése pedig a 95\%-ot is elérte (Krajkó 1987, 38). 
Gyuris Ferenc : Az orosz ipar történeti fejlödésének politikai, ágazati és térbeli vonatkozásai.

Tér és Társadalom 23. évf. 2009/4. 173-187. p.

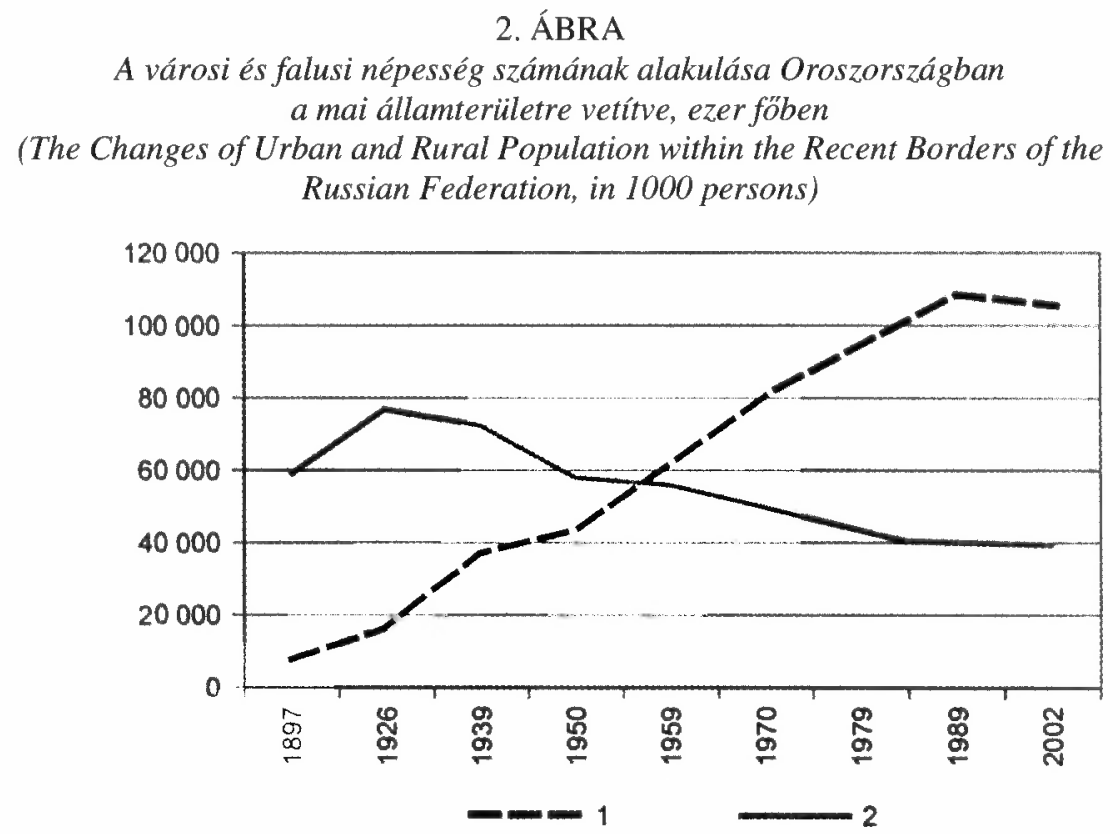

Jelmagyarázat: 1 - Városi népesség; 2 - Falusi népesség.

Forrás: Federel'naja szluzsba goszudarsztvennoj sztatyisztyiki alapjăn a szerzõ szerkesztése.

Forrás: Nefjodova $(2008,2$. ábra).

A bolsevikok győzelme, illetve a Szovjetunió 1922-es kikiáltása után alapvető fordulat történt az állam iparhoz való viszonyában. Az egyeduralkodóvá váló marxista-leninista ideológiával összhangban a szovjet vezetés a munkásosztályban látta társadalmi bázisát, ami e réteg megerősítésére, ennek érdekében pedig az ipar (kiemelten a nagyüzemi nehézipar) erőteljes fejlesztésére sarkallta. Ez a szándék erỏltetett urbanizációs törekvéssel is együtt járt. A feudalista múltat jelképező falusias vidékkel szemben az újonnan (vagy korábban is meglévő települések gyökeres átalakításával) létrehozott szocialista iparvárosok egyszerre voltak hivatottak az új nagyüzemekben dolgozó tömegek lakhatásának és infrastrukturális ellátásának költséghatékony biztosítására, valamint - a városi társadalom könnyebb központi megfigyelése, kontrollja révén - a „szocialista embertípus” kialakítását elősegítő térbeli keretrendszer megteremtésére. A fenti törekvések és a beruházások szinte kizárólagos állami irányítása révén olyan, sok évtizedes folyamat vette kezdetét, amely a Szovjetunió 1991-es felbomlásáig az ipari szektor gazdasági súlyának, valamint a városi népesség számának, illetve arányának látványos és folyamatos növekedését hozta magával. Az iparban foglalkoztatottak aránya 1920-1991 között 3\%-ról 40\% fölé, a városlakók aránya 1913-1984 között 18\%-ról 65\%-ra emelkedett (2. ábra) (Krajkó 1987, 30; Trejvis 2008, 173).

Fontos azonban, hogy az iparosítás és városfejlesztés prioritásának állandósága mellett az évtizedek során jelentős változások történtek a beruházások ágazati és 
Gyuris Ferenc : Az orosz ipar történeti fejlödésének politikai, ágazati és térbeli vonatkozásai. Tér és Társadalom 23. évf. 2009/4. 173-187. p.

területi vonatkozásaiban, sôt a célok megvalósításának technikai megoldásaiban is. A formálódó szovjethatalom fỏ célja a kezdeti esztendőkben a háború utáni újjáépítés volt, melynek megvalósítása a hadikommunizmus keretei közt indult el. Ezt a rendszert váltotta fel 1920-ban az új gazdaságpolitika, a NEP, amely az üzemegységek önállóságának bizonyos fokú növelésével kívánta elősegíteni az ipar talpra állását. Egy évvel később aztán elfogadták az ország villamosítási koncepcióját, a GOELRO-tervet, amely a Szovjetunió első iparosítási programjának tekinthető (Horváth 2008, 16-17).

A terv a cári időszak ipari folyamataihoz képest több újszerủ vonást tartalmazott. Az egyik a koncepcionális háttér: az ipar országos léptékủ, központilag irányított fejlesztésének gondolata volt. A másik az ágazati hangsúlyok eltolódása, hiszen érdemi (ipar)történeti előzmény nélkül, de kiemelt prioritásként fogalmazódott meg a villamosenergia-ipar fejlesztése, elsősorban grandiózus vízerömü-építések révén. A program ugyanakkor egy markáns vonatkozásban a háború elötti hagyományokat követte: a beruházások több mint fele a régi ipari térségek közelében valósult meg, döntően az európai országrészen. Az ipar térszerkezetében tehát nem történt jelentỏs változás, annak ellenére, hogy a területi különbségek mérséklése a politikai vezetés egyik hangsúlyos céljaként fogalmazódott meg (Horváth 2008, 16).

Lenin 1924-ben bekövetkezett halála, Sztálin totális hatalmának kiépülése jelentős politikai változást hozott a Szovjetunió történetében, az iparpolitika fó céljai azonban nem változtak. Az 1928-ban meghirdetett első, majd a második ötéves terv a Lenin idején kijelölt ágazati célokat követte, és az ipar térszerkezetében, a régi iparvidékek dominanciájában sem hozott jelentékeny változást (jellemző, hogy Moszkva és a Moszkvai terület ipari kibocsátása még a harmincas évek végén is jóval nagyobb volt, mint egész Szibériáé) (Horváth 2008, 18).

A sztálini iparpolitika e szakaszának újszerüsége az alkalmazott módszerekben, illetve - ezzel összefüggésben - a célok és az eredmények volumenében áltt. A NEP leállítását követően az iparfejlesztésben a szélsőséges centralizmus időszaka kezdődött el, melynek során a töke- és munkaerőforrásokat nem kímélve igyekeztek gyorsítani az ország iparosodását. Ennek a „fejlesztési koncepciónak” integráns részét képezték a GULAG lágereiben embertelen körülmények között dolgoztatott kényszermunkások milliói is, akiknek a vezetés kiemelten nagy szerepet szánt a legzordabb országrészek építkezéseinek megvalósításában. A sztálini gazdaságpolitika eredménye a foglalkozási átrétegződés drámai felgyorsulásában (az ipari foglalkoztatottak aránya 1930-1940 között mintegy 5\%-ról közel 30\%-ra emelkedett) (Trejvis 2008, 173), illetve az ipari össztermelés látványos (1913 és 1940 között nyolcszoros) növekedésében nyilvánult meg (Krajkó 1987, 39). Megjegyzendő, hogy bár a Szovjetunió a nemzetközi munkamegosztásba - saját antikapitalista, illetve a nyugati világ antikommunista ideológiája miatt - alig kapcsolódott be, a tỏkehiány és a technológiai elmaradottság cári időszak óta fennálló problémáját a szovjet vezetés (többek közt) jelentős mennyiségủ külföldi pénz- és „tudástőke” bevonásával próbálta orvosolni. Számos amerikai és német cég komoly szerepet kapott a monumentális duzzasztógátak, a 
Gyuris Ferenc : Az orosz ipar történeti fejlödésének politikai, ágazati és térbeli vonatkozásai.

Tér és Társadalom 23. évf. 2009/4. 173-187. p.

TÉT XXIII. évf. 2009 " 4

gyáróriások, söt az ezek köré épülö újvárosok megtervezésében, egyes beruházások kivitelezésében (Heller-Nyekrics 1996, 178-180).

A szovjet ipar ágazati és területi szerkezetében a II. világháború hozott drámai változást. A támadó német csapatok rohamos elöretörése, a heves harcok során teljes városok dőltek romba, a nyugati országrész ipari kapacitásainak jelentős részét (mintegy 1300 nagyüzemet) azonban sikerült áttelepíteni az Urál térségébe, valamint az ázsiai országrészbe. A harcoló csapatok utánpótlásának biztosítására új üzemek sorát (több mint 2000 gyárat) kellett létrehozni, ezek is szinte kivétel nélkül a keleti országrészbe települtek (Krajkó 1987, 39). Jellemző, hogy 1942-43-ban a Szovjetunió összes beruházásainak közel 40\%-a az Urál térségében és NyugatSzibériában valósult meg (Antal 1980, 20). Ez a kényszerhelyzet adta meg az első érdemi lökést az Európa-centrikus ipari térszerkezet átalakításának. A háborús helyzet az ipar ágazati szerkezetében is komoly változást hozott: néhány esztendő leforgása alatt a hadiipari tevékenységek rohamos térnyerésére került sor. Ez alapozta meg a szovjet gazdaság tulajdonképpen egyetlen, minőségi téren is nemzetközileg versenyképes feldolgozóipari ágazatának fejlődését.

A háború utáni beruházások, minthogy kezdetben a nyugati területek újjáépítésére összpontosítottak, az európai országrész ipari jelentőségének átmeneti visszaerősödését hozták. Az 1940-es évek végétől beinduló hosszú távú iparosítási programok azonban kiemelt szerepet szántak az ázsiai országrész fejlesztésének. Szibériára és az orosz Távol-Keletre elsősorban a kiaknázatlan eróforrások ,tárházaként” tekintettek, amely alkalmasnak tủnt a szovjet gazdaság rohamosan bövülő nyersanyag- és energiaigényének fedezésére. Ebből fakadóan a keleti országrészen szén- és ércbányák sokasága létesült, felgyorsult a tajga erdő́llományának kitermelése, a szibériai folyamokon pedig óriási vízerőművek épültek (jellemző, hogy Oroszország mai államterületére vetítve az ázsiai országrész elektromosenergia-termelésen belüli súlya 1940 és 1960 között 9,2\%-ról 21,6\%-ra emelkedett) (Horváth 2008, 20). A komoly természetátalakítással (gyakorta ökológiai rombolással) járó beruházások - a többé-kevésbé racionális gazdasági és stratégiai célok mellett - nyilvánvaló presztízsszempontokat is szolgáltak. Különösen a hatalmas duzzasztógátak és a szállítási lehetőségek javítását célzó csatornaépítések voltak hivatottak annak bizonyítására, hogy a szovjet társadalom képes legyőzni a természetet (földrajzi nihilizmus), ami a kapitalista társadalmakkal szembeni felsőbbrendüségét bizonyítja (Hajdú 1999; v. ö. Kovda 1951). Ez a politikai motívum különösen erős lökést adott a hasonló beruházásoknak.

Az ázsiai országrész gazdasági jelentősége a Nyugat-szibériai-alföld roppant szénhidrogén-készleteinek feltárása és meginduló kitermelése révén az 1970-es évektől tovább nőtt. Több ezer kilométernyi új csővezeték építése révén a térség nemcsak a Szovjetunió európai körzeteinek, hanem a teljes kelet-európai blokk meghatározó szénhidrogén-ellátójává vált. A gyorsan növekvő kitermelés jelentős Nyugat-Európába irányuló exportra is lehetöséget adott, amely a szocialista nagyhatalom legfontosabb keményvaluta-forrásává vált.

Az Urálon túli térségek kitermelőiparára tekintélyes alapanyaggyártás (pl. fafeldolgozás, cellulózipar, cementgyártás) települt, és jelentỏs feldolgozóipari beruhá- 
Gyuris Ferenc : Az orosz ipar történeti fejlödésének politikai, ágazati és térbeli vonatkozásai. Tér és Társadalom 23. évf. 2009/4. 173-187. p.

TÉT XXIII. évf. 2009 a 4

Kitekintö

179

zásokra is sor került. Utóbbiak jórészt a már meglévő ázsiai ipari körzetekben (pl. a Kuznyecki-medencében) valósultak meg (Klüter 1997). Ezen túl jelentös kohászati fejlesztések történtek a nagyon távoli fekvésủ bányászati központokban (a 69. északi szélességen található Norilszkben például a világ legnagyobb kapacitású nikkelkombinátja létesült), illetve a vízerőmú-városokban (Bratszkban a Föld legnagyobb alumíniumkohója épült fel) (Klüter 2000, 14).

Paradox módon az ázsiai országrész fejlesztésekor annak földrajzi elszigeteltsége és nehéz megközelíthetősége is pozitív tényezőnek minősült, mivel az Egyesült Államokkal rivalizáló Szovjetunió az ipari térszerkezet alakításakor kiemelt figyelmet fordított a katonai-stratégiai szempontokra. Ennek köszönhetően a hadiipari fejlesztés és gyártás tekintélyes részét telepítették az ázsiai körzetekbe - jelentős részben újonnan, kimondottan e célból létrehozott, a külvilágtól elzárt, hivatalosan nem is létező „zárt városokba” (Bucharin-Cochran-Norris 1999).

Az ázsiai körzetek ipari termelésének dinamikus növeléséhez elengedhetetlen volt a szükséges munkaerö biztosítása, melyhez - nevezett országrészek rendkívül alacsony népsürüsége révén - csak a más országrészekbỏl való bevándorlás fokozásával volt lehetőség. A sztálini időszak erőszakos népesség-áttelepítési hullámaival szemben (a politikai rendszer „enyhülésének” jeleként) az 1950-es évek végétól már az anyagi ösztönzők, köztük a garantált többletszabadság és a különleges bérpótlékok váltak hivatottá a munkaerő keletre vonzására. Igaz, a keletre áramló foglalkoztatottak zöme a zord természeti körülmények (pl. az akár több hónapig tartó téli éjszaka, a rendkívüli hideg stb.) miatt néhány év után visszatért az európai térségbe, helyükre azonban a kedvező anyagi feltételeknek köszönhetően újabbak érkeztek (Rudl 1999, 36-37). Ennek köszönhetően az ázsiai országrész lakosainak száma folyamatosan növekedett: 1940-1979 között 18,2 millió föről 29,2 millióra, miáltal a térség részesedése az Orosz SZSZK népességéböl 16,6\%-ról 21,2\%-ra emelkedett ${ }^{1}$. A többnyire fiatal munkavállalók elhelyezése érdekében új lendületet kapott a szocialista városfejlesztés, mely az észak-ázsiai országrészben sok, általában elözmény nélküli település gyors kialakítását jelentette.

A szovjet éra nagy léptékủ, az ipari termelés ágazati és területi képét egyaránt markánsan átformáló indusztrializációs folyamatai sajátos területi szervezési elvek mentén valósultak meg. Nagytérségi szinten a szocialista területi politika célja ún. területi-termelési komplexumok létrehozása volt, melyek erősen centralizált, eltérő termelési profilú körzeteket átfogó, gazdaságilag összességében önellátó területegységek voltak (vagy annak kellett volna lenniük) (Pilipenko 2008). A szovjet politika központosításba és tervezésbe vetett hitét tükrözö, látszólag racionális szemlélet azonban a gyakorlatban oda vezetett, hogy adott komplexumon belül - a méretgazdaságosság jegyében - egész városokat, sőt kisebb körzeteket szerveztek kevés, sok esetben egyetlen gazdasági tevékenység köré. Az Udmurt Köztársaságban például a hadiipar, Togliattiban az autógyártás (VAZ/Lada), az Ivanovói területen pedig a textilipar adta az ipari termelés döntő többségét (Horváth 2008, 35). Utóbbi felduzzasztott könnyüipari kapacitására jellemző, hogy az 1960-as évektől a rendszerváltásig az Ivanovói terület adta az Orosz SZSZK teljes textilipari termelésének két- 
Gyuris Ferenc : Az orosz ipar történeti fejlödésének politikai, ágazati és térbeli vonatkozásai.

Tér és Társadalom 23. évf. 2009/4. 173-187. p.

180 Kitekintor

TÉT XXIII. évf. 2009 a 4

harmadát (Trejvis 2008, 191). Figyelembe véve, hogy a legtöbb nagyvárosban a szociális szféra megszervezése is a helyi nagyüzem feladatkörébe tartozott (Horváth 2008, 35), sok esetben nemcsak a gazdaság, hanem a lakosság életének szinte minden szegmense egyetlen ágazat helyzetétöl függött. Az viszont, hogy a végletes ágazati egyoldalúság e térségeket potenciálisan erösen sebezhetővé teszi, a piacidegen megoldások sokaságával operáló szovjet gazdaság keretei között - az 1990es évekig - rejtve maradt.

\section{Oroszország ipara a rendszerváltás után}

A szocialista iparfejlesztés markáns sajátosságokkal bíró, kétségkívül jelentős eredményeket felmutató, ám számos (részint rejtett) problémát generáló évtizedei a Szovjetunió 1991-es szétesésével, a politikai és gazdasági rendszerben bekövetkező radikális fordulattal lezárultak. A Borisz Jelcin vezette Oroszország a piacgazdasági fejlődés útjára lépett, ami a központi tervezés és az állami kontroll határozott gyengülését, a piacidegen gazdaságszervezési és -fejlesztési módszerek zömének gyors feladását eredményezte, különösen, hogy utóbbiak fenntartását az elhatalmasodó forráshiány sem tette lehetővé. Az ország helyzetét a gazdasági átmenet „természetes" velejárói mellett tovább nehezítette a KGST és a Szovjetunió széthullása, a külkereskedelmi kapcsolatok ebből fakadó meggyengülése. Mindezek révén igen súlyos, elhúzódó gazdasági visszaesés következett be: Oroszország egy före jutó GDP-je 1990-1998 között reálértéken háromötödére csökkent (Maddison 2009), a megélénkülés első érdemi jelei pedig az ezredfordulóig várattak magukra.

Bár a recesszió mindhárom gazdasági szektort súlyosan érintette, az ipar visszaesése különösen nagymértékủ volt: az ipari termelés 1998-ra az 1990-es érték 45\%-ára csökkent (Zubarevics 2008, 156). Ennek következtében a szekunder szektor még a jelentősen zsugorodó gazdaságon belül is veszített relatív súlyából. Míg 1990-ben a foglalkoztatottak 40,2\%-a dolgozott az iparban és az építöiparban, ez az érték 1996-ra 32,6\%-ra, 2007-re pedig 28,9\%-ra csökkent. Ezzel párhuzamosan a szekunder szektor GDP-hez való hozzájárulása ugyanezen időpontok között 45,9\%ról 36,0\%-ra, majd 31,6\%-ra apadt (Horváth 2008, 13-14; illetve Goskomstat...é.n.).

A politikai és gazdasági körülmények változása révén a korábban töretlen urbanizációs folyamat is megakadt. A városi lakosság aránya az 1980-as évek vége óta stabilan 73\%-on áll (Goskomstat... é.n.), ami az ország népességének természetes fogyását figyelembe véve csökkenő abszolút lélekszámot jelent. Különösen erős negatív tendenciák tapasztalhatók a kis- és középvárosok esetében, ahonnan a munkahelyüiket elvesztő aktív korú lakosok jelentős része költözik az olcsóbb létfenntartási lehetőségekkel kecsegtető - fỏként az európai országrész déli körzetében található agrárterületekre. Lényegesen kedvezöbb az 500000 fö fölötti nagyvárosok helyzete, ezek ugyanis sokoldalú gazdaságszerkezetük révén jellemzően a rendszerváltozás 
Gyuris Ferenc : Az orosz ipar történeti fejlödésének politikai, ágazati és térbeli vonatkozásai. Tér és Társadalom 23. évf. 2009/4. 173-187. p.

után is ,talpon tudtak maradni", többnyire megőrizték pozitív vándorlási egyenlegüket (részint Zubarevics 2003 nyomán Nefjodova 2008, 397-398; 401).

Az ipar 1991 utáni általános visszaesése mögött komoly ágazati és területi különbségek húzódnak (1. táblázat). Az átmenet legnagyobb vesztesének a hagyományos könnyüipari ágazatok, a textil- és böripar tekinthetők, melyek termelése 2000-re az 1991-es érték negyedére-hatodára zsugorodott, és - az ezredforduló óta tapasztalható növekedési fázis ellenére - 2007-ben is több mint $70 \%$-kal maradt el az 1991-estöl. Ezek az ágazatok piacgazdasági viszonyok közepette képtelenek voltak állni a versenyt az alacsony bérköltségekkel termelö, főként dél- és délkelet-ázsiai fejlödő országokkal.

A rendszerváltás egyértelmủ vesztesei közé tartoznak azok az alacsony hozzáadott értéket produkáló, gyakorlatilag nyersanyagtermelö tevékenységek, mint a nemenergiahordozó ásványkincsek bányászata, a nemfémes bányakincsek feldolgozása, a tüzelőanyag-gyártás, illetve a faipar. A fenti ágazatok hanyatlása részint a rájuk épuilö hazai ipari tevékenységek hanyatlásával magyarázható, ami a nyersanyagszuikséglet drámai csökkenését eredményezte, fơként, hogy a rendszerváltás során jellemzően a legkisebb nyersanyag- és energiahatékonysággal múködő (relatíve legnagyobb fogyasztású) nehézipari üzemek zártak be először. A másik fontos ok az előállítási költségek rohamos emelkedésében keresendő. A szovjet időkben a szállítást központilag erősen dotálták, miáltal a zömmel távoli országrészekben kitermelt (és esetenként feldolgozott) nyersanyagok olcsón eljuttathatók voltak az Orosz SZSZK európai ipari körzeteibe, sőt részint versenyképes exportcikket képeztek (ez a megoldás piacidegen jellegével együtt összhangban volt az önellátásra törekvés politikai szándékával). A közlekedési, szállítási szolgáltatások piackonform átszervezése viszont a szállítási költségek tetemes növekedéséhez vezetett, miáltal a hazai nyersanyagok felhasználása immár gyakorta drágább megoldásnak bizonyul a - fokozatosan felfutó - importnál (Klüter 1997, 727; 2000, 16).

A rendszerváltás jelentős és tartós hanyatlást hozott két, hagyományosan tőkeigényesnek és így magas színvonalúnak tekintett ágazatban, a gép- és a jármủgyártásban is. Ez egyrészt abból fakad, hogy számos gépipari szegmensben különösen erősen érvényesült a szovjet ipar nemzetközi élmezőnyhöz viszonyított minőségi hátránya. Másfelól a valóban magas technikai színvonalat képviselő hadiipar az átmenet egyik legnagyobb vesztesévé vált, minthogy a Szovjetunió szétesése és a hidegháború befejeződése révén drasztikus visszaesés történt a hazai katonai megrendelésekben. Ezt a hadiipari export sem tudta ellensúlyozni, mivel a termelés visszaesése az alkatrészutánpótlás biztonságát is aláásta, jelentősen rontva az orosz katonai termékek nemzetközi versenyképességét (a helyzetet egyes termékcsoportoknál - pl. a harci repülők esetében - az üzemeltetés magas költsége is rontja) (Malek 2003).

Néhány ágazat ugyanakkor képes volt kiheverni a rendszerváltozás okozta sokkot. Az utóbbi esztendókben már az 1990-es értéket jelentősen meghaladó termelési érték jellemzi az energiahordozó-bányászatot. Ez tekintélyes mennyiségủ kőolaj és földgáz exportját teszi lehetővé a kelet-, közép- és nyugat-európai országokba, miáltal az egész orosz gazdaság egyik legfontosabb - igaz, közel sem kizárólagos - 
Gyuris Ferenc : Az orosz ipar történeti fejlödésének politikai, ágazati és térbeli vonatkozásai.

Tér és Társadalom 23. évf. 2009/4. 173-187. p.

bevételi forrásának tekinthetô (Köves 2005; Deák 2008, 27). Az ágazat dinamikájához hozzájárul, hogy bár a világpiaci árak változására meglehetôsen érzékeny, a termékei iránti európai kereslet meglehetösen stabil. Az 1990-es évek gazdasági kríziséből képes volt kilábalni a kitermelt szénhidrogének feldolgozására épülö mủanyaggyártás, valamint az északi tajgaerdők roppant faállományára alapozott papíripar is.

Megállapítható ugyanakkor, hogy Oroszország ezredforduló óta tapasztalható gazdasági növekedéséhez az ipar részéröl zömmel a nyersanyag-kitermelő vagy ezekhez kapcsolódó, félkész termékeket előállító ágazatok járultak hozzá. A tőkeintenzív, tudásigényes tevékenységek közül kizárólag - a hagyományosan fóként katonai célokat szolgáló - elektronikai ipar tudott bekerülni a dinamikusan fejlödő ipari tevékenységek körébe.

\section{TÁBLÁZAT}

Az iparágazatok ipari termelési értéke az 1990-es volumen százalékában

(The Production Value of the Industrial Branches Compared to the Value in 1990 as 100)

\begin{tabular}{|c|c|c|}
\hline Ágazat & 2000 & 2007 \\
\hline Bányászat & 74,3 & 103,5 \\
\hline Energiahordozók bányászata & 80,9 & 116,6 \\
\hline Egyéb ásványkincsek bányászata & 60,0 & 64,7 \\
\hline Feldolgozóipar & 51,0 & 81,8 \\
\hline Élelmiszeripar & 54,5 & 85,4 \\
\hline Textilipar & 23,4 & 27,4 \\
\hline Bőripar & 15,5 & 26,6 \\
\hline Faipar & 37,5 & 53,4 \\
\hline Papír- és nyomdaipar & 81,2 & 126,9 \\
\hline Tüzelöanyag-gyártás & 60,1 & 77,8 \\
\hline Vegyipar & 69,8 & 91,1 \\
\hline Gumi- és mủanyaggyártás & 52,5 & 110,5 \\
\hline Nemfémes ásványkincsek feldolgozása & 40,3 & 65,8 \\
\hline Fémipar & 66,8 & 98,2 \\
\hline Gépgyártás & 32,3 & 58,7 \\
\hline Elektronikai ipar & 45,3 & 151,3 \\
\hline Jármủgyártás & 53,1 & 63,2 \\
\hline Egyéb feldolgozóipar & 60,4 & 106,6 \\
\hline Áram-, gáz-és vízellátás & 76,9 & 90,1 \\
\hline
\end{tabular}

Forrás: Saját szerkesztés a Goskomstat... (é.n.) adatai alapján.

Természetesen figyelembe kell vennünk, hogy az egyes ágazatok termelésének összesített adatsorai mögött az üzemegységek szintjén rendkívül eltérő fejlödési pályák húzódnak. Jellemző példa, hogy a 2007-ben az 1990-eshez hasonló kibocsátással rendelkezó fémipar mutatói mögött egyszerre mutatható ki számtalan, elavult technológiával termelö üzem (akár teljes ipari körzetek) drámai leépülése, valamint még a szovjet időszakban komoly korszerúsítésen átesett gyáróriások (pl. Lipeck), illetve a rendkívül értékes színesfémet termelő (pl. Norilszk, Magnyitogorszk) kohászati létesít- 
Gyuris Ferenc : Az orosz ipar történeti fejlödésének politikai, ágazati és térbeli vonatkozásai. Tér és Társadalom 23. évf. 2009/4. 173-187. p.

mények relatív „szárnyalása” (Norilszk az orosz városok rangsorában a teljes ipari termelés alapján az 1980-as 40. helyről 2000-re a 3. helyre ugrott előre) (BradeSchulze 2003, 34-35). Hasonlóképpen a jármügyártás egyes emblematikus vállalatai - az ágazat általános visszaesése ellenére - ma is stabilan őrzik pozíciójukat, jórészt annak köszönhetően, hogy technikailag elavult termékeikre a kedvezö árak miatt viszonylag stabil kereslet mutatkozik a hazai piacon (ennek tipikus példája a Lada típusú személygépkocsikat is gyártó VAZ Togliattiban) (Horváth 2008, 47).

A rendszerváltás eredményeképpen jelentös átrendeződés történt Oroszország iparának területi szerkezetében is (3. ábra). Ennek legfőbb jellemzője az ipari termelés térbeli koncentrációjának markáns fokozódása a legdinamikusabb ágazatok erós térbeli koncentráltságának köszönhetően. Az ország fö szénhidrogén-termelő központja, a Tyumenyi oblaszty, valamint a Hanti-Manysi és a Jamali-Nyenyec autonóm okrug 1990-ben együittesen az orosz ipar termelésének 3,5\%-át adta, 2006-ban már 14,9\%-át. Hasonlóképpen a legkorszerübb ipari tevékenységek (és a $\mathrm{K}+\mathrm{F}$ kapacitások) zömét tömörítő Moszkva város részaránya ugyanebben az időszakban 6,8\%-ról 11,4\%-ra emelkedett (Goskomstat... é.n.), dacára az itt tapasztalható markáns tercierizálódási tendenciáknak, az ïzleti szolgáltató szektor térnyerésének (utóbbiról 1. Gritsai 1997).

Ezzel egy időben az európai országrész legtöbb térségének súlya az ipari termelésben jelentősen csökkent. Az itteni feldolgozóipar kétszeresen is megszenvedte a piaci nyitást. Termékeinek zöme alacsony müszaki színvonala miatt nem tudott versenyre kelni az import árukkal, miközben a szállítási költségek hirtelen megugrása rendkívül drágává tette a létfontosságú nyersanyagok (jórészt az ázsiai országrészből történő) beszerzését, ezáltal a termelést. Az ipari termelés alakulását illetően a gazdasági átalakulás nagy vesztesének tekinthetjük az ázsiai országrész zömét is. Az Urálon túli térség egyetlen komoly ipari körzete, a dél-szibériai iparvidék - az európai térségekhez hasonlóan - a szállítási költségek drámai emelkedése miatt vesztette el versenyképességét, termékei ugyanis mind az európai országrészbe, mind a nemzetközi (európai, illetve távol-keleti) piacokra csak több ezer kilométeres szállítással juttathatók el. Részben ugyanez a probléma sújtotta a távol-keleti régiót, ahol viszont a szovjet érában létező különleges bérpótlékok markáns csökkenése, valamint a létfenntartási költségek drasztikus emelkedése a népesség (és így a munkaerő) számának drasztikus apadásához vezetett. A távol-keleti szövetségi körzet népességének 19,3\%-át vesztette el 1990 és 2006 között, de a Magadani oblasztyban 56,1\%, Csukcsföldön 68,4\% volt ugyanez az érték (Regioni Rosszii $2007,2.1$. táblázat) ${ }^{2}$. Utóbbi tendencia úgy is értelmezhető, mint azoknak az országrészeknek a gazdasági „,föladása”, melyek bizonyos fokú integrálása és fejlesztése a szovjet időszak autark gazdaságpolitikája szempontjából alapvető és logikus cél volt, piaci körülmények között azonban versenyképes ipar fenntartására alkalmatlannak bizonyulnak. 
Gyuris Ferenc : Az orosz ipar történeti fejlödésének politikai, ágazati és térbeli vonatkozásai.

Tér és Társadalom 23. évf. 2009/4. 173-187. p.

184 Kitekintó

TÉT XXIII. évf. 2009 a 4

\section{3. ÁBRA}

Oroszország szubjektumainak százalékos részesedése az országos ipari termelésból 1990-ben és 2006-ban

(The Share of the Russian Regions of the National Industrial Production in 1990 and in 2006)

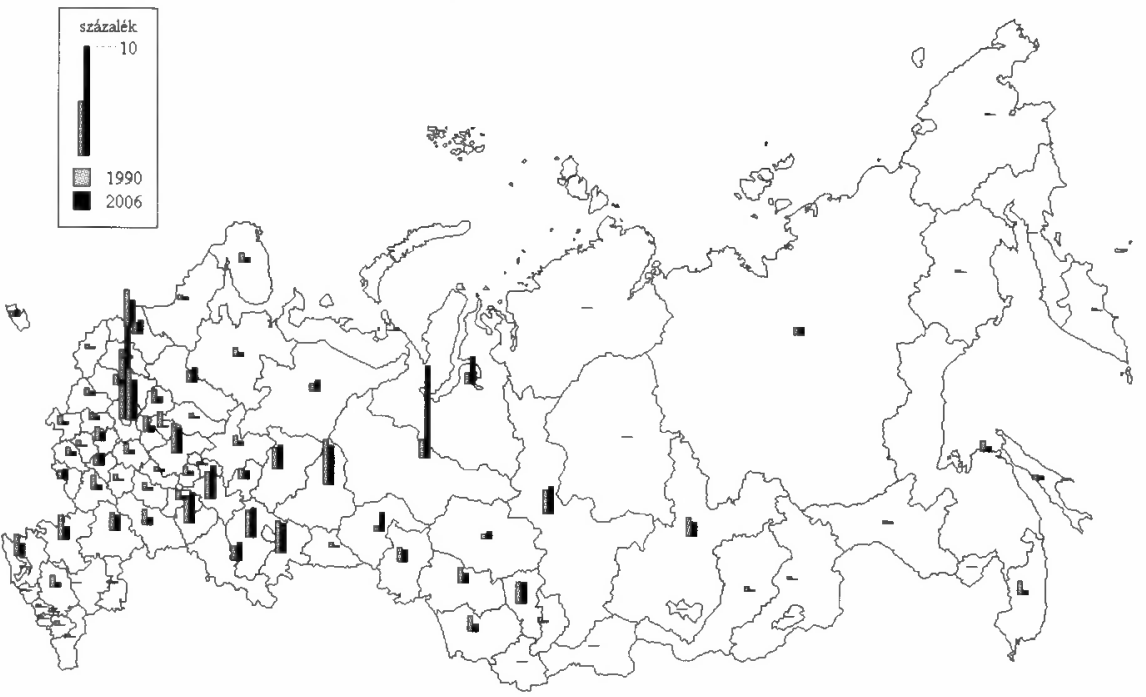

Forrás: Saját szerkesztés a Regioni Rosszii (2003, 13-1. táblázat; 2007, 13-1. táblázat) adatai alapján.

A szállítási és kommunális (pl. fütési) költségek drámai növekedése csak két ázsiai térségben nem vezetett az ipar rendkívül erös visszaeséséhez: ezek a Kuznyeckimedence „motorját” képezỏ Kemerovói oblaszty, valamint a Krasznojarszki kraj, melyek ipari kibocsátása az orosz átlagnál kevésbé esett vissza. A kedvezö tendencia azonban döntően az állami beavatkozásnak köszönhetö, amely még a legsúlyosabb forráshiány esztendeiben is próbálta mérsékelni a körzet visszaesését, a tömeges munkanélküliség és az ebböl fakadó társadalmi, politikai feszülttségek elkerülése végett (különösen azt figyelembe véve, hogy a térségben az 1980-as évek vége óta többször került sor a hatalommal szembeni jelentös politikai megmozdulásokra, fóként sztrájkokra) (Klüter 1997, 723).

Oroszország iparának rendszerváltás utáni tendenciái összességében azt tükrözik, hogy a kapitalista viszonyok kiépülése alapvetően átrajzolta a szocialista érában kialakult képet. Ez területi szempontból a távoli országrészek rendkívül drágán kiépített termelési rendszerének drámai leépülését, más részről a hagyományosan fontos ipari centrum, Moszkva súlyának növekedését jelenti. Strukturális tekintetben azoknak az ágazatoknak a mély válságát tapasztalhatjuk, melyeket a Szovjetunió idején túlfejlesztettek, és többnyire már akkor is piacidegen módszerekkel tartottak fent. A rendszerváltás okozta sokkot néhány fejlett ipari tevékenység mellett gyakorlatilag a - cári idökben is az orosz ipar gerincét alkotó - kitermelöipari szektor 
Gyuris Ferenc : Az orosz ipar történeti fejlödésének politikai, ágazati és térbeli vonatkozásai. Tér és Társadalom 23. évf. 2009/4. 173-187. p.

TÉT XXIII. évf. 2009 - 4

Kitekintö

185

volt képes kiheverni. Mindez azt jelenti, hogy bár a szovjet iparpolitika hatásai feltehetően még sokáig fellelhetök lesznek Oroszország gazdaságföldrajzi térképén, az 1991 utáni időszak területi és ágazati értelemben is a szocialista örökség jelentős részének feladását, sok tekintetben a szovjet éra elötti sémák bizonyos fokú újraéledését hozta magával.

\section{Összegzés}

Oroszország a 20. század elején - fejlődésének történelmi megkésettsége révén az iparilag elmaradott országok közé tartozott, a következő száz esztendőben viszont tekintélyes eredményeket ért el az ipar fejlesztésében, és a nemzetközi ipari termelés meghatározó szereplői közé emelkedett.

A cári időkben még csak gyenge ipari bázissal rendelkező orosz gazdaság indusztrializációja a szocializmus idején vett komoly lendületet, ami döntően a kommunista vezetés ideológiai irányultságából fakadt. Ennek egyik fontos sarokpontját a marxista-leninista eszmerendszer határozott iparpártisága jelentette. Alapvetóen az ideológiai háttérben gyökerezett a kommunista rendszerek centralizált sémákban gondolkodó tervező szemlélete is, amely először adott lehetőséget a nemzeti erőforrások - jellemzően más ágazatok kárára történő - iparfejlesztési célú összpontosítására. Nagy jelentősége volt annak a szempontnak is, hogy a sztálini Szovjetunió a szocializmus világméretü győzelmét elhozni hivatott harmadik világháborúra készült. Ez különösen nagy lendületet adott a nehézipari és hadiipari fejlesztésnek, lehetőség szerint a stratégiai szempontból védhetö, nehezen elérhetö országrészekben, melyek korábban érdemi iparral nem rendelkeztek. Az elmaradott körzetek iparosítása azonban nem csak ezt a - maga módján logikus - szempontot követte, hanem segítette a politika egalitárius elveinek megvalósítását, nem mellesleg pedig a környezet legyőzésének képességét igazolva a szocialista rendszerek „imázsépítését" is szolgálta.

Fontos ugyanakkor kiemelnünk, hogy az orosz ipar fejlödése/fejlesztése még egyazon gazdaság- és politikatörténeti korszakon belül, akár egy vezető uralma idején is mutatott jelentős kilengéseket, melyeket a külföldi hatások éppúgy befolyásoltak, mint a vezető nézetrendszerének kisebb-nagyobb változásai. Vitathatatlan továbbá, hogy a rendszer totalitárius jellegéból fakadóan az ország iparosítása morálisan teljességgel elfogadhatatlanul játszódott le, és szörnyư emberáldozatokat követelt.

Miként a szocialista rendszer kiépítése alapvető változást hozott az ország életében, hasonló átrendezödést eredményeztek azok a gazdasági változások is, amelyek idỏvel a kapitalista gazdálkodás kibontakozásához vezettek. A gorbacsovi periódus fokozatos gazdasági és politikai reformjai után a kilencvenes évek eleje a korábbi rendszer összeomlását és egy újnak a kiépülését hozta. A többé-kevésbé eredményes (bár meglehetősen felemás) demokratizálódási és gazdasági liberalizációs folyamatok alaposan megbolygatták a szocialista éra ipari örökségét. Az ipari termelés drasztikus visszaesése mellett ez teljes ágazatok leépülését, valamint az 
országos gazdasági, ipari vérkeringésbe oriási áldozatok árán bekapcsolt országrészek hanyatlását hozta magával. Összességében azt mondhatjuk: Földünk legnagyobb területü országa, miközben kétségtelenül magán viseli a szovjet éra iparfejlesztésének nyomait, iparának területi és ágazati szerkezetét, az európai országrész feldolgozóipari túlsúlyát és a kitermelöipar rendkívüli részarányát tekintve sok szempontból nagyobb hasonlóságot mutat a cári Oroszországgal, mint a szuperhatalmi státuszának csúcsán álló Szovjetunióval.

\section{Jegyzetek}

\footnotetext{
${ }^{1}$ Saját számítás Antal (1980, 45-47), valamint a Population statistics:... (é.n.) adatai alapján.

${ }^{2}$ Ráadásul az ennél is drámaibb elvándorlást sok esetben csak az akadályozta meg, hogy a népesség jelentős részének nem volt kellö anyagi háttere az áttelepüléshez (Wites 2006, 193).
}

\section{Irodalom}

Antal Z. (1980) Szovjetunió. II. kötet. Gazdaságföldrajz. Gondolat Kiadó, Budapest.

Brade, I.-Schulze, M. (2003) Die russischen Städte im Umbruch. Gewinner und Verlierer des Transformationsprozesses. - Geographische Rundschau. 12. 34-40. o.

Bucharin, O.-Cochran, Th.B.-Norris, R.S. (1999) New Perspectives on Russia's Ten Secret Cities. Nuclear Weapons Databook. National Resources Defence Council, Nuclear Program, Washington. http://docs.nrdc.org/nuclear/nuc_10019901a_208b.pdf

CIA World Factbook 2008. https://www.cia.gov/library/publications/the-world-factbook/index.html

Deák A.Gy. (2008) Új kontextusban az orosz energetika. - Nemzet és Biztonság. 1. 20-30. o.

Goskomstat. Russia in figures. (é.n.) http://www.gks.ru

Gritsai, O. (1997) The economic restructuring of Moscow in the international context. - GeoJoumal. 4. 341-347. o.

Hajdú Z. (1999) Környezet és politika: a természetátalakítás ,zseniális” sztálini terve. - Tóth J.-Wilhelm Z. (szerk.) Változó kömyezetünk. Janus Pannonius Tudományegyetem, Pécs. 131-145. o.

Heller, M.-Nyekrics, A. (1996) Orosz történelem, II. kötet. A Szovjetunió története. Osiris Kiadó, Budapest.

Horváth Gy. (2008) Regionális átalakulás Oroszországban. - Horváth Gy. (szerk.) Regionális fejlődés és politika az átalakuló Oroszországban. MTA RKK, Pécs. 11-62. o.

Klüter, H. (1997) Das Kuzneck-Becken. - Geographische Rundschau. 12. 723-729. o.

Klüter, H. (2000) Der Norden Russlands - vom Niedergang einer Entwicklungsregion. - Geographische Rundschau. 12. 12-20. o.

Kovda, V.A. (1951) A kommunizmus nagy alkotásai és a természet átalakítása. - A szovjet nép átalakítja a természetet. Cikkgyüjtemény. Szikra, Budapest. 5-22. o.

Köves, A. (2005) Oil and Economy. A Contribution to the Discussion on Russian Economic Development. - Acta Oeconomica. 4. 371-402. o.

Krajkó Gy. (1987) A Szovjetunió gazdaságföldrajza. Tankönyvkiadó, Budapest.

Maddison, A. (2009) Statistics on World Population, GDP and Per Capita GDP, 1-2006 AD. http://www.ggdc.net/maddison/Historical_Statistics/horizontal-file_03-2009.xls

Malek, M. (2003) Rüstungsindustrie und Rüstungsexport Rußlands: Zustand, Probleme und Perspektiven, - Österreichische Osthefte. 3-4. 516-534. o.

Nefjodova, T. (2008) Az orosz perifériák terjeszkedése. - Horváth Gy. (szerk.) Regionális fejlódés és politika az átalakulo Oroszországban. MTA RKK, Pécs. 397-421. o.

Pilipenko, I. (2008) Klaszterek és területi-termelési komplexumok a regionális fejlödésben. - Horváth Gy. (szerk.) Regionális fejlödés és politika az átalakuló Oroszországban. MTA RKK, Pécs. 328-341. o.

Population statistics: historical demography. (é.n.) http://www.populstat.info 
Gyuris Ferenc : Az orosz ipar történeti fejlödésének politikai, ágazati és térbeli vonatkozásai. Tér és Társadalom 23. évf. 2009/4. 173-187. p.

\section{TÉT XXIII. évf. 2009}

Kitekintö

Regioni Rosszii. (2003) Sztatiszticseszkij szbornik; szocialno-ekonomicseszkie pokazateli. Oficialnoje Izdanyije. Roszsztat, Moszkva.

Regioni Rosszii. (2007) Sztatiszticseszkij szbornik: szocialno-ekonomicseszkie pokazateli. Oficialnoje Izdanyije. Roszsztat, Moszkva.

Rudl J. (1999) A Szovjetunió utódállamainak földrajza. Dialóg Campus Kiadó, Budapest-Pécs.

Trejvis, A. (2008) Posztindusztriális regionális folyamatok és a régiók újraiparosítása. - Horváth Gy. (szerk.) Regionális fejlödés és politika az átalakuló Oroszországban. MTA RKK, Pécs. 171-198. o.

Wites, T. (2006) Depopulation of the Russian Far East. Magadan Oblast: A case Study. - Miscellanea Geographica. 12. 185-196. 0.

Zubarevics, N. (2003) Szocial'noje razvityie regionov Rosszii: problemi i tendencii perehodnovo perioda. URSZSZ, Moszkva.

Zubarevics, N. (2008) A területi különbségek alakulása. - Horváth Gy. (szerk.) Regionális fejlódés és politika az átalakuló Oroszországban. MTA RKK, Pécs. 151-170. o. 